\title{
DETERMINAN PENERAPAN 3M PLUS OLEH PENDERITA DBD DI WILAYAH KERJA PUSKESMAS PAYUNG SEKAKI KECAMATAN PAYUNG SEKAKI KOTA PEKANBARU
}

\author{
Zulmeliza Rasyid, Nurvi Susanti, Nofri Hasrianto \\ Program Studi Kesehatan Masyarakat STIKes Hang Tuah \\ Email : zulmeliza.rasyid@gmail.com
}

\begin{abstract}
ABSTRAK
Penerapan $3 M$ Plus adalah segala bentuk kegiatan pencegahan menaburkan bubuk larvasida pada tempat penampungan air yang sulit dibersihkan, menggunakan obat nyamuk atau anti nyamuk, menggunakan kelambu saat tidur, memelihara ikan pemangsa jentik nyamuk, menanam tanaman pengusir nyamuk, mengatur cahaya,ventilasi dalam rumah, menghindari kebiasaan menggantung pakaian di dalam rumah yang bias menjadi tempat istirahat nyamuk. Data angka kejadian DBD di wilayah kerja puskesmas Payung Sekaki Tahun 2016 sebanyak 145 orang , jumlah kematian 1 orang. Tujuan penelitian ini adalah untuk mengetahui determinan penerapan 3M Plus .Desain yang digunakan pada penelitian ini adalah analitik kuantitatif dengan pendekatan cross sectional. Sampel penelitian ini seluruh penderita DBD Di Wilayah Kerja Puskesmas Payung Sekaki sebanyak 145 orang. Metode pengambilan sampel dilakukan secara Quota Sampling. Pengolahan data secara komputerisasi. Analisis yang digunakan analisis univariat, bivariate dan multivariat. Hasil uji chi square antara Pengetahuan dengan penerapan 3 M Plus diperoleh $p$ value=0,000, Sikap dengan penerapan 3M Plus diperoleh pvalue=0,000, Tindakan penerapan 3 M Plus diperoleh $p$ value $=0,000$ sedangkan variabel yang dominan berpengaruh adalah Sikap dengan $p$ value = 0,000 POR (95\% CI ) 6.155 (2,437-15,554). Disarankan kepada pihak puskesmas untuk dapat memaksimalkan pemberian informasi kesehatan oleh petugas kesehatan dalam menyebarluaska informasi ataupun penyuluhan tentang penerapan 3 M Plus.
\end{abstract}

\section{Kata Kunci : Penerapan 3M Plus, Pengetahuan, Sikap dan Tindakan}

\section{PENDAHULUAN}

Setiap tahun, kejadian penyakit demam berdarah dengue (DBD) di Indonesia cenderung meningkat pada pertengahan musim penghujan sekitar bulan Januari, dan cenderung turun pada bulan Februari hingga ke penghujung tahun.Sepanjang Januari 2016 Direktorat Pengendalian Penyakit Tular Vektor dan Zoonosis Kementerian Kesehatan mencatat 3.298 kasus DBD dengan jumlah kematian sebanyak 50 kasus di Indonesia. Sementara di daerah KLB tercatat 492 kasus, 25 kasus diantaranya meninggal. KLB terjadi di 11 Kabupaten/Kota di 7 Provinsi.

Dalam penanganan DBD, peran serta masyarakat untuk menekan kasus ini sangat menentukan. Oleh karenanya program Pemberantasan Sarang Nyamuk (PSN) dengan cara 3M Plus perlu terus dilakukan secara berkelanjutan sepanjang tahun khususnya pada musim penghujan. Program PSN , yaitu: 1) Menguras, adalah membersihkan tempat yang sering dijadikan tempat penampungan air seperti bak mandi, ember air, tempat penampungan air minum, penampung air lemari es dan lain-lain 2) Menutup, yaitu menutup rapat-rapat tempat-tempat penampungan air seperti drum, kendi, toren air, dan lain sebagainya; dan 3) Memanfaatkan kembali atau mendaur ulang barang bekas yang memiliki potensi untuk jadi tempat perkembangbiakan nyamuk penular Demam Berdarah.

PSN (Pemberantasan Sarang Nyamuk) yaitu upaya untuk mengurangi jumlah nyamuk dengan melakukan pemberantasan pada jentiknya. Pemberantasan jentik nyamuk adalah suatu tindakan yang dilakukan untuk membasmi atau memberantas telur, jentik, dan kepompong nyamuk dengan berbagai cara, dengan tujuan untuk menekan laju pertumbuhan nyamuk. PSN merupakan cara pengendalian vektor sebagai salah satu upaya yang dilakukan untuk mencegah terjadinya 
penularan penyakit. Kampanye PSN sudah digalakkan pemerintah dalam hal ini Departemen Kesehatan dengan semboyan 3M Plus. Adapun cara yang efektik untuk dilakukan dalam perilaku PSN ialah penerapan gerakan 3M Plus.

PSN perlu ditingkatkan terutama pada musim penghujan dan pancaroba, karena meningkatnya curah hujan dapat meningkatkan tempat-tempat perkembangbiakan nyamuk penular DBD, sehingga seringkali menimbulkan kejadian luar biasa (KLB) terutama pada saat musim penghujan.

3M yang dimaksud adalah menguras, menutup, dan mengubur atau mendaur ulang barang bekas yang memiliki potensi untuk jadi tempat perkembangbiakan nyamuk. Sedangkan yang dimaksud dengan "Plus" adalah segala bentuk kegiatan pencegahan seperti menaburkan bubuk larvasida pada tempat penampungan air yang sulit dibersihkan, menggunakan obat nyamuk atau anti nyamuk, menanam tanaman pengusir nyamuk seperti serai dll, serta rutinitas menjaga kebersihan lingkungan dan pribadi.

Adapun yang dimaksud dengan 3M Plus adalah segala bentuk kegiatan pencegahan seperti 1) Menaburkan bubuk larvasida pada tempat penampungan air yang sulit dibersihkan; 2) Menggunakan obat nyamuk atau anti nyamuk; 3) Menggunakan kelambu saat tidur; 4) Memelihara ikan pemangsa jentik nyamuk; 5) Menanam tanaman pengusir nyamuk, 6) Mengatur cahaya dan ventilasi dalam rumah; 7) Menghindari kebiasaan menggantung pakaian di dalam rumah yang bisa menjadi tempat istirahat nyamuk, dan lain-lain. (WHO 2009).

Praktik PSN 3M plus dapat dikatakan berjalan dengan baik adalah apabila seseorang telah melaksanakan kegiatan PSN 3M plus di lingkungan rumahnya (WHO 2009) secara rutin dan berkesinambungan (Notoatmodjo 2007).

Terjadinya KLB DBD di Indonesia berhubungan dengan berbagai faktor risiko, yaitu: 1) Lingkungan yang masih kondusif untuk terjadinya tempat perindukan nyamuk Aedes; 2) Pemahaman masyarakat yang masih terbatas mengenai pentingnya pemberantasan sarang nyamuk (PSN) dan tidak masuk menerapkan 3M Plus; 3) Perluasan daerah endemic akibat perubahan dan manipulasi lingkungan yang etrjadi karena urbanisasi dan pembangunan tempat pemukiman baru; serta 4) Meningkatnya mobilitas penduduk.

Demam Berdarah Dengue (DBD) adalah penyakit menular yang disebabkan oleh virus dengue dan ditularkan oleh nyamuk Aedes aegypti danAedes albopictus, Vektor ini, secara biologis dan bionomiknya selalu berdekatan dan berhubungan dengan kehidupan manusia, Selain itu untuk mengendalikan populasi Aedes aegypti dan Aedes albopictus terutama dilakukan dengan cara pengelolaan lingkungan(Yunanda 2016).

Virus dengue dilaporkan telah menjangkiti lebih dari 100 Negara, terutama di daerah Perkotaan yang berpenduduk padat dan pemukiman di Brazil dan bagian lain Amerika Selatan, Karibia, Asia Tenggara, dan India. Jumlah orang yang terinfeksi diperkirakan sekitar 50 sampai 100 juta orang, setengahnya dirawat di rumah sakit dan mengakibatkan 22.000 kematian setiap tahun, diperkirakan 2,5 miliar orang atau hampir 40 persen populasi dunia, tinggal di daerah endemis DBD yang memungkinkan terinfeksi virus dengue melalui gigitan nyamuk setempat (WHO, 2009)

Demam berdarah dengue (DBD) sebagai salah satu penyakit yang harus mendapat perhatian dan senantiasa diupayakan cara pengobatan dan pengendaliannya agar tidak meluas dan memakan korban jiwa lebih banyak. Data WHO menunjukkan bahwa sebanyak 2,5 sampai 3 milyar penduduk dunia terinfeksi virus dengue dan setiap tahunnya terdapat 50-100 juta penduduk dunia terinfeksi virus ini. 50 ribu di antaranya membutuhkan perawatan intensif di fasilitas pelayanan kesehatan. Sejak Tahun 1968 hingga sekarang, WHO mencatat negara Indonesia sebagai negara dengan kasus DBD tertinggi di Asia Tenggara. (WHO, 2009). 
Di Indonesia pada tahun 2015 jumlah penderita DBD yang dilaporkan sebanyak 129.650 kasus dengan jumlah kematian sebanyak 1.071 orang. Dibandingkan tahun 2014 dengan kasus sebanyak 100.347 dengan kata lain terjadi peningkatan kasus pada tahun 2015. Target Renstra Kementerian Kesehatan untuk angka kesakitan DBD tahun 2015 sebesar < 49 per 100.000 penduduk, dengan demikian Indonesia belum mencapai target Renstra 2015. (Profil Kesehatan Nasional Tahun 2015).

Sedangkan di Provinsi Riau, jumlah kasus DBD yang dilaporkan pada tahun 2015 sebanyak 3.261 orang ( $I R=51,4$ per 100.000 penduduk) dan angka kematian sebanyak 20 orang. Trend angka kesakitan DBD di Provinsi Riau semakin meningkat sejak tahun 2012. Pada tahun 2015 terjadi peningkatan angka kesakitan DBD sebanyak 13,17 per 100.000 penduduk dibandingkan pada tahun 2014 (Profil Kesehatan Provinsi Riau tahun 2015).

Di Pekanbaru sendiri angka kesakitannya sudah memenuhi indikator Propinsi (IR $<50$ per 100.000 penduduk), tetapi belum memenuhi indikator Nasional (IR < 49 per 100.000 penduduk) seperti terlihat pada tabel di atas. Sedangkan wilayah pada kecamatan di pekanbaru pada tahun 2016 menunjukkan data DBD tertinggi terletak pada kecamatan Payung Sekaki yaitu 145 orang dengan jumlah kematian 1 orang.

Berdasarkan data Dinas Kesehatan Kota Pekanbaru tahun 2016, puskesmas yang ada di Pekanbaru sebanyak 20 Puskesmas. Jumlah kasus DBD tertinggi terdapat di Puskesmas Payung Sekaki dengan jumlah 145 Kasus.

Berdasarkan Profil Puskesmas Payung Sekaki tahun 2016 yang terdiri dari empat Kelurahan yaitu Kelurahan Labuh Baru Barat, Kelurahan Labuh Baru Timur, Kelurahan Air Hitam, Kelurahan Tampan. Jumlah kasus DBD tahun 2014 sebanyak 34 kasus dan tahun 2016 meningkat sebanyak 145 kasus, berdasarkan hasil wawancara dengan Petugas Kesehatan di Puskesmas Payung Sekaki, bahwa Petugas Kesehatan terkait telah melakukan penyuluhan dengan Indikator
Demam Berdarah Dengue (DBD) setiap bulan. Baik di dalam gedung maupun luar gedung. Pada Tahun 2016 Kelurahan Labuh Baru Timur memiliki data tertinggi penderita DBD sebanyak 62 orang, Kelurahan Labuh Baru Barat dengan jumlah 51 penderita dengan jumlah 1 kematian.

Berdasarkan dari latar belakang diatas, tingginya kasus DBD dikarenakan oleh penderita DBD tidak mau menerapkan 3M Plus di lingkungan sekitarnya. Oleh karena itu nyamuk penular DBD masih banyak bertebangan di daerah tersebut sehingga kemungkinan untuk terjadinya DBD akan semakin besar. Untuk itu perlu dilakukan upaya penerapan $3 \mathrm{M}$ Plus pada penderita DBDnya dan peneliti tertarik untuk melakukan penelitian dengan judul "Determinan Penerapan 3M Plus oleh Penderita DBD di Wilayah Kerja Puskesmas Payung Sekaki Kecamatan Payung Sekaki tahun 2016" dengan tujuan agar angka kasus demam berdarah dengue (DBD) ini dapat diminimalisir.

\section{METODE PENELITIAN}

Rancangan penelitian ini bersifat analitik kuantitatif observasional dengan desain Cross Sectional yaitu penelitian yang pengukuran variabel independen dan variabel dependen yang dilakukan hanya satu kali dalam waktu yang bersamaan.

Unit analisis dalam penelitian ini adalah seluruh penderita DBD yang berada di wilayah kerja Puskesmas Payung Sekaki Kecamatan Payung Sekaki berjumlah 145 Penderita.Objek penelitian ini adalah menggunakan sampel jenuh (total Sampling) yaitu seluruh penderita DBD yang berada di wilayah kerja Puskesmas Payung Sekaki.

Alat penelitian yang digunakan dalam penelitian ini adalah kuesioner yang berisi tentang pertanyaan terstruktur meliputi pengetahuan, sikap dan tindakan responden terhadap penerapan $3 \mathrm{M}$ plus.

Metode penelitian yang dilakukan dalam penelitian ini menggunakan metode wawancara dan observasi langsung ke 
lapangan dengan menggunakan panduan pertanyaan yaitu kuesioner yang bertujuan untuk mengetahui pengetahuan, sikap dan tindakan responden terhadap penerapan $3 \mathrm{M}$ Plus dilingkungan tempat tinggalnya.

Teknik pengumpulan data dilakukan secara Quota Sampling denganyaitu teknik pengambilan sampel dengan cara menetapkan sejumlah anggota sampel secara quotum atau jatah. Teknik ini digunakan dengan cara pertama-tama menetapkan berapa besar jumlah sampel yang diperlukan atau menetapkan quotum (jatah yang kemudian jumlah itulah yang dijadikan dasar untuk mengambil unit sampel yang dibutuhkan.
Analisis data yang digunakan dalam penelitian ini adalah analisa univariat yang bertujuanuntukmenggambarkan distribusi frekuensidari masing-masing variabel independen dan dependen dan analisis bivariat yang bertujuan untuk mengetahui hubungan antara variabel independen dengan variabel dependen dengan derajat kepercayaan CI95\%. Jika $\mathrm{p}$ value $\leq 0,05$ berarti terdapat hubungan yang signifikan antara variabel independen dengan variabel dependen. Serta analisis multivariat yaitu analisis yang bertujuan untuk mengetahui variabel independen yang dominan berpengaruh terhadap variabel dependen.Variabel dan Definisi Operasional penelitian ini dapat dilihat pada tabel dibawah ini :

\section{Tabel 1 Definisi Operasional}

\begin{tabular}{|c|c|c|c|c|c|c|}
\hline No & $\begin{array}{r}\text { Variabel } \\
\text { Penelitian } \\
\end{array}$ & Defenisi Operasional & Alat Ukur & Cara Ukur & Skala Ukur & Hasil Ukur \\
\hline 1 & $\begin{array}{l}\text { Penerapan } \\
\text { 3M Plus }\end{array}$ & $\begin{array}{l}\text { Perilaku Responden } \\
\text { yang Menerapkan 3M } \\
\text { Plus }\end{array}$ & Kuesioner & $\begin{array}{l}\text { Mengisi } \\
\text { kuesioner }\end{array}$ & Ordinal & $\begin{array}{l}\text { 0. Tidak } \\
\text { Menerapkanjika } \leq \\
\text { mean (3) } \\
\text { 1.Menerapkanjika } \\
>\text { mean (3) }\end{array}$ \\
\hline 2 & Pengetahu & $\begin{array}{l}\text { Pemahaman Responden } \\
\text { dalam pentingnya } \\
\text { penerapan 3M Plus } \\
\text { dengan } \\
\text { Kejadian DBD. }\end{array}$ & Kuesioner & $\begin{array}{l}\text { Mengisi } \\
\text { kuesioner }\end{array}$ & Ordinal & $\begin{array}{l}0 . \text { Kurang, jika } \leq \\
\text { mean }(5) \\
1 . \text { Baik, jika }> \\
\text { mean }(5)\end{array}$ \\
\hline 3 & Sikap & $\begin{array}{l}\text { Sikap responden } \\
\text { terhadap } \\
\text { penerapan } 3 \mathrm{M} \text { Plus } \\
\text { dengan } \\
\text { Kejadian DBD } \\
\end{array}$ & Kuesioner & $\begin{array}{l}\text { Mengisi } \\
\text { kuesioner }\end{array}$ & Ordinal & $\begin{array}{l}0 . \text { negatif, jika } \leq \\
\text { mean (3) } \\
1 . \text { Positif, jika > } \\
\text { mean (3) }\end{array}$ \\
\hline 4 & Tindakan & $\begin{array}{l}\text { Tindakan responden } \\
\text { terhadap } \\
\text { penerapan } 3 \mathrm{M} \text { Plus } \\
\text { dengan } \\
\text { Kejadian DBD }\end{array}$ & Kuesioner & $\begin{array}{l}\text { Mengisi } \\
\text { kuesioner }\end{array}$ & Nominal & $\begin{array}{l}0 . \text { Kurang, jika } \leq \\
\text { mean }(3) \\
1 . \text { Baik, jika }> \\
\text { mean (3) }\end{array}$ \\
\hline
\end{tabular}




\section{HASIL DAN PEMBAHASAN}

\section{A Analisis Univariat}

Tabel 2 Resume Univariat variabel Independen dan variabel Dependen Penerapan 3M Plus di Wilayah Kerja Puskesmas Payung Sekaki

\begin{tabular}{lrr}
$\begin{array}{l}\text { Penerapan 3M } \\
\text { Plus }\end{array}$ & n & \% \\
\hline Tidak & 100 & 69,0 \\
$\begin{array}{l}\text { Menerapkan } \\
\text { Menerapkan }\end{array}$ & 45 & 31,0 \\
Pengetahuan & & \\
Kurang & 118 & 81,4 \\
Baik & 27 & 18,6 \\
Sikap & & \\
\hline
\end{tabular}

\begin{tabular}{lrr}
\hline Negatif & 108 & 74,5 \\
Positif & 37 & 25,5 \\
Tindakan & & \\
Kurang & 105 & 72,4 \\
Baik & 40 & 27,6 \\
\hline
\end{tabular}

Berdasarkan tabel 2 diatas diperoleh bahwa mayoritas responden tidak menerapkan $3 \mathrm{M}$ Plus sebesar (69\%), pengetahuan responden yang kurang tentang penerapan $3 \mathrm{M}$ plus sebesar $(81,4 \%)$, sikap responden yang negatif sebesar $(74,5 \%)$ serta tindakan responden yang kurang baik dalam penerapan $3 \mathrm{M}$ plus sebesar $(72,4 \%)$

\section{A. Analisis Bivariat}

Tabel 3 Hubungan Pengetahuan Responden dengan Penerapan 3M Plus oleh Penderita DBD

\begin{tabular}{|c|c|c|c|c|c|c|c|}
\hline \multirow[t]{2}{*}{ Pengetahuan } & Tida & apkan & \multicolumn{2}{|c|}{$\begin{array}{c}\text { Penerapan 3M Plus } \\
\text { Menerapkan }\end{array}$} & \multirow{2}{*}{$\frac{\text { Total }}{\text { n }(\%)}$} & \multirow[t]{2}{*}{ P Value } & \multirow[t]{2}{*}{$\begin{array}{c}\text { POR } \\
(95 \% \mathrm{CI})\end{array}$} \\
\hline & $\mathbf{n}$ & $\%$ & $\mathbf{n}$ & $\%$ & & & \\
\hline Kurang & 90 & 76,3 & 28 & 23,7 & $118(100)$ & 0,000 & 5,464 \\
\hline Baik & 10 & 37 & 17 & 63 & $27(100)$ & & $(2,247-13,290)$ \\
\hline Total & 100 & 69 & 45 & 31 & $145(100)$ & & \\
\hline
\end{tabular}

Berdasarkan tabel 3 diatas diperoleh bahwa dari 118 responden dengan pengetahuan yang kurang terdapat 90 $(76,3 \%)$ responden tidak menerapkan $3 \mathrm{M}$ Plus. Sedangkan dari 27 responden dengan pengetahuan yang baik terdapat $10(37 \%)$ responden tidak menerapkan $3 \mathrm{M}$ Plus.

Dari hasil uji statistik diperoleh bahwa $\mathrm{P}$ Value $=0,000$, maka dapat disimpulkan bahwa terdapat hubungan yang signifikan antara pengetahuan responden dengan penerapan $3 \mathrm{M}$ Plus. Dan juga diperoleh nilai POR $(95 \% \mathrm{CI})=$ $5,464(2,247-13,290)$ yang artinya adalah pengetahuan responden yang kurang berpeluang 5 kali untuk tidak menerapkan $3 \mathrm{M}$ plus dibandingkan dengan pengetahuan responden yang baik.

Tabel 4 Hubungan Sikap Responden dengan Penerapan 3M Plus oleh Penderita DBD

\begin{tabular}{|c|c|c|c|c|c|c|c|}
\hline \multirow{3}{*}{ Sikap } & \multicolumn{5}{|c|}{ Penerapan 3M Plus } & \multirow{3}{*}{ P Value } & \multirow{3}{*}{$\begin{array}{c}\text { POR } \\
(95 \% \mathrm{CI})\end{array}$} \\
\hline & \multicolumn{2}{|c|}{ Tidak Menerapkan } & \multicolumn{2}{|c|}{ Menerapkan } & Total & & \\
\hline & $\mathrm{n}$ & $\%$ & $\mathrm{n}$ & $\%$ & $\mathrm{n}(\%)$ & & \\
\hline Negatif & 86 & 79,6 & 22 & 20,4 & $108(100)$ & & 6,422 \\
\hline Positif & 14 & 37,8 & 23 & 62,2 & $37(100)$ & 0,000 & $(2,849-14,477)$ \\
\hline Total & 100 & 69 & 45 & 31 & $145(100)$ & & \\
\hline
\end{tabular}

Berdasarkan tabel 4 diatas diperoleh bahwa dari 108 responden dengan sikap yang negatif terdapat $86(79,6 \%)$ responden tidak menerapkan 3M Plus. Sedangkan dari 
37 responden dengan sikap yang positif terdapat $14 \quad(37,8 \%)$ responden tidak menerapkan 3M Plus.

Dari hasil uji statistik diperoleh bahwa $\mathrm{P}$ Value $=0,000$, maka dapat disimpulkan bahwa terdapat hubungan yang signifikan antara sikap responden dengan penerapan
3M Plus. Dan juga diperoleh nilai POR $(95 \% \mathrm{CI})=6,422(2,849-14,477)$ yang artinya adalah sikap responden yang negatif berpeluang 6 kali untuk tidak menerapkan $3 \mathrm{M}$ plus dibandingkan dengan sikap responden yang positif.

Tabel 4 Hubungan Tindakan Responden dengan Penerapan 3M Plus oleh Penderita DBD

\begin{tabular}{|c|c|c|c|c|c|c|c|}
\hline \multirow{3}{*}{ Tindakan } & \multicolumn{5}{|c|}{$\begin{array}{l}\text { PENERAPAN 3M PLUS } \\
\end{array}$} & \multirow{3}{*}{ P Value } & \multirow{3}{*}{$\begin{array}{c}\text { POR } \\
(95 \% \mathrm{CI})\end{array}$} \\
\hline & \multicolumn{2}{|c|}{ Tidak Menerapkan } & \multicolumn{2}{|c|}{ Menerapkan } & \multirow{2}{*}{$\begin{array}{c}\text { Total } \\
\text { n }(\%)\end{array}$} & & \\
\hline & n & $\%$ & $\mathbf{n}$ & $\%$ & & & \\
\hline Kurang & 83 & 79 & 22 & 21 & $105(100)$ & & 5,104 \\
\hline Baik & 17 & 42,5 & 23 & 57,5 & $40(100)$ & 0,000 & $(2,332-11,174)$ \\
\hline Total & 100 & 69 & 45 & 31 & $145(100)$ & & \\
\hline
\end{tabular}

Berdasarkan tabel 5 diatas diperoleh bahwa dari 105 responden dengan tindakan yang kurang terdapat $83(79 \%)$ responden tidak menerapkan $3 \mathrm{M}$ Plus. Sedangkan dari 40 responden dengan pengetahuan yang baik terdapat $17(42,5 \%)$ responden tidak menerapkan 3M Plus.

Dari hasil uji statistik diperoleh bahwa $\mathrm{P}$ Value $=0,000$, maka dapat disimpulkan bahwa terdapat hubungan yang signifikan antara tindakan responden dengan penerapan $3 \mathrm{M}$ Plus. Dan juga diperoleh nilai POR $(95 \% \mathrm{CI})=$ $5,104(2,332-11,174)$ yang artinya adalah tindakan responden yang kurang berpeluang 5 kali untuk tidak menerapkan $3 \mathrm{M}$ plus dibandingkan dengan tindakan responden yang baik.

\section{B. Analisis Multivariat}

Tabel 6 Hasil Seleksi Analisis Bivariat Determinan Penerapan 3M Plus oleh Penderita DBD

\begin{tabular}{clcl}
\hline No & $\begin{array}{c}\text { Variabel } \\
\text { Independen }\end{array}$ & P Value & Keterangan \\
\hline 1 & Pengetahuan & 0,000 & Kandidat \\
2 & Sikap & 0,000 & Kandidat \\
3 & Tindakan & 0,000 & Kandidat \\
\hline
\end{tabular}

Tabel 6 menunjukkan bahwa dimana ketiga variabel independen merupakan kandidat, oleh karena itu variabel independen tersebut masuk ke tahappemodelan multivariat (nilai $p<0,25$ )

\section{Tabel 7 Pemodelan Multivariat 1}

\begin{tabular}{llccccc}
\hline & \multirow{2}{*}{ Variabel } & P & \multicolumn{2}{c}{$\mathbf{9 5 \%}$ CI for EXB (B) } \\
\cline { 4 - 6 } & Independen & Value & $\begin{array}{c}\text { Exp } \\
(\mathbf{B})\end{array}$ & Lower & Upper \\
\hline 1 & Pengetahuan & 0.006 & 4.442 & 1,543 & 12,797 \\
2 & Sikap & 0.000 & 6,155 & 2,437 & 15,544 \\
3 & Tindakan & 0,001 & 5,006 & 2,018 & 12,417 \\
\hline
\end{tabular}

Pada tabel 7 diatas terlihat bahwa semua variabel yang $p$ valuenya $<0,05$. Dapat disimpulkan bahwa variabel yang paling dominan berpengaruh terhadap penerapan $3 \mathrm{M}$ Plus adalah variabel sikap ( $\mathrm{P}$ Value $=0,000)$ dan POR $(95 \% \mathrm{CI})=6,155(2,437-15,544)$ yang artinya bahwa sikap responden yang negatif lebih berpengaruh untuk tidak menerapkan $3 \mathrm{M}$ Plus dibandingkan dengan sikap responden yang negatif.

\section{C.Pembahasan}

Hubungan pengetahuan dengan Penerapan 3M Plus oleh Penderita DBD di Wilayah Kerja Puskesmas Payung Sekaki Kecamatan Payung Sekaki Tahun 2016

Berdasarkan hasil penelitian diperoleh bahwa terdapat hubungan antara pengetahuan dengan Penerapan 3M Plus oleh Penderita 
DBD di Wilayah Kerja PuskesmasPayung Sekaki Kecamatan Payung Sekaki Tahun 2016 $(\mathrm{P}$ Value $=0,000)$

Menurut Roger (1985) bahwa pengetahuan tentang suatu objek tertentu sangat penting terjadinnya perubahan perilaku yang merupakan proses yang sangat kompleks. Pengetahuan responden tentang DBD dapat diperoleh dari kabar berita tentang DBD yang tersiar diberbagai media masa atau penyuluhan petugas kesehatan, dimana media tersebut juga berperan penting dalam penyampaian informasi dan berpotensi untuk mempengaruhi perilaku masyarakat. Berdasarkan Skiner perilaku dalam kejadian DBD seseorang baru akan melaksankan 3M Plus jika dia atau keluargannya sendiri berisiko terkena DBD namun jika ia merasa aman dia tidak perlu untuk melakukannya.

Hasil penelitian ini juga sejalan dengan penelitian yang dilakukan oleh Puspaningrum (2004) Ada hubungan bermakna antara penerapan $3 \mathrm{M}$ Plus ( $\mathrm{p}=0,007)$ dengan demikian hal ini mendukung peneliti ini dimana secara tidak langsung dapat dikatakan bahwa pengetahuan memberi pengaruh nyata terhadap penerapan $3 \mathrm{M}$ Plus.

Adanya hubungan antara pengetahuan dengan penerapan 3M Plus, hal ini dikarenakan bahwa dimana proporsi pengetahuann kurang dan baik berbeda secara nyata. Hal ini disebabkan oleh tingkat pendidikan responden yang cenderung berada pada pendidikan rendah, dapat dilihat dari hasil pengamatan dilapangan bahwa banyak responden yang membuang sampah sembarangan dan tidak mengubur sampahsampah bekas yang dapat menampung air, selain itu tempat penampungan air dirumah mereka dibiarkan terbuka, kondisi ini menggambarkan bahwa responden tidak mengetahui dampak dari tidak mengubur sampah bekas maupun dampak dari tidak menutup tempat penampungan air dirumah mereka, dengan demikian responden yang memiliki pengetahuan kurang tidak termotivasi untuk melakukan tenpenerapan 3M Plus di rumah maupun lingkungan sekitarnya.
Hubungan Sikap dengan Penerapan 3M Plus oleh Penderita DBD di Wilayah Kerja Puskesmas Payung Sekaki Kecamatan Payung Sekaki Tahun 2016

Berdasarkan hasil penelitian diperoleh bahwa terdapat hubungan antara sikap dengan Penerapan 3M Plus oleh Penderita DBD di Wilayah Kerja PuskesmasPayung Sekaki Kecamatan Payung Sekaki Tahun 2016 (P Value $=0,000$ ).

Sikap adalah reaksi atau respon yang masih tertutup dari seseorang terhadap stimulus atau objek, baik yang bersifat interen maupun eksteren sehingga manifestasi dari sikap tidak dapat langsung dilihat, tetapi hanya dapat ditafsirkan terlebih dahulu dari perilaku yang tertutup tersebut. Tingkatan sikap adalah menerima, merespon, menghargai, dan bertanggung jawab. Sikap seseorang sangat mempengaruhi perilaku baik sikap positif maupun negatif (Notoatmodjo, 2009). Sikap Positif akan lebih cenderung mau melakukan dan menerapkan $3 \mathrm{M}$ Plus di bandingkan dengan responden dengan sikap Negatif

Menurut Utamadi (2010), selain pengetahuan,penerapan 3M Plus juga dapat disebabkan oleh faktor sikap seseorang. Masyarakat yang memliki sikap negatif, akan kurang menyadari akan pentingnya penerapan $3 \mathrm{M}$ plus dalam rangka melakukan pencegahan DBD.

Hasil penelitian diatas sejalan dengan penelitian Adri (2016), dimana hasil penelitian terdapat hubungan yang signifikan antara sikap terhadap penerapan 3M Plus oleh penderita DBD di Kecamatan Baiturrahman dengan ( $p$ value $=<0,002$ )

Berdasarkan hasil penelitian dan teori diatas, peneliti menyimpulkan adanya hubungan antara sikap dengan penerapan $3 \mathrm{M}$ Plus didasar oleh sebagian responden memiliki sikap yang negatif terhadap masalah penerapan 3M Plus, hal ini dapat dilihat dari hasil pengamatan respoden yang tidak peduli terhadap lingkungan dan dan kesehatannya. Kebanyakan responden yang membuang sampah sembarangan dan tidak mengubur sampah-sampah bekas yang dapat menampung 
air, selain itu tempat penampungan air dirumah mereka dibiarkan terbuka, yang berdampak terhadap kejadian DBD

\section{Hubungan Tindakan dengan Penerapan 3M Plus oleh Penderita DBD di Wilayah Kerja Puskesmas Payung Sekaki Kecamatan Payung Sekaki Tahun 2016}

Berdasarkan hasil penelitian diperoleh bahwa terdapat hubungan antara tindakan dengan Penerapan 3M Plus oleh Penderita DBD di Wilayah Kerja PuskesmasPayung Sekaki Kecamatan Payung Sekaki Tahun 2016 $(\mathrm{P}$ Value $=0,000)$

Hasil penelitian ini sejalan dengan teori yaitu tindakan adalah suatu sikap belum otomatis terwujud dalam suatu tindakan (overt behavior). Untuk mewujudkan sikap menjadi suatu yang nyata diperlukanfaktor pendukung atau suatu kondisi yang memungkinkan seperti tindakan penerapan $3 \mathrm{M}$ plus oleh penderita DBD.

Hasil penelitian in juga sejalan dengan penelitian yang dilakukan oleh Warsito (2005) yang menyatakan bahwa ada hubungan yang bermakna antara tidakan responden terhadap penerapn 3M Plus dengan ( $\mathrm{P}$ Value $<0,0001$ ).

Adanya hubungan antara pengetahuan dengan penerapan 3M Plus, hal ini dikarenakan bahwa respondengantindakan kurang lebih banyak dibandingkan dengan tindakan baik, namun tidak baik tidak mencerminkan penerapan 3M Plus mungkin ini disebabkan kurangnnya kesadaran dan keyakinan untuk menjalankan tindakan penerapan 3M Plus oleh penderita DBD secara maksimal dan terus menerus.

\section{KESIMPULAN DAN SARAN}

\section{A. Kesimpulan}

Berdasarkan hasil penelitian maka dapat disimpulkan bahwa :

1. Mayoritas responden tidak menerapkan $3 \mathrm{M}$ Plus sebesar $69 \%$

2. Terdapat hubungan antara pengetahuan dengan penerapan $3 \mathrm{M}$ di Wilayah Kerja
Puskesmas Payung Sekaki Kecamatan Payung Sekaki Tahun 2016 ( $\mathrm{P}$ value = $0,000)$

3. Terdapat hubungan antara sikap dengan penerapan 3M di Wilayah Kerja Puskesmas Payung Sekaki Kecamatan Payung Sekaki Tahun $2016(\mathrm{P}$ value $=0,000)$

4. Terdapat hubungan antara tindakan dengan penerapan 3M di Wilayah Kerja Puskesmas Payung Sekaki Kecamatan Payung Sekaki Tahun $2016(\mathrm{P}$ value $=0,000)$

5. Variabel yang paling dominan berpengaruh terhadap penerapan 3M di Wilayah Kerja Puskesmas Payung Sekaki Kecamatan Payung Sekaki Tahun 2016 adalah variabel sikap $(\mathrm{P}$ value $=0,000)$ dan POR $(95 \% \mathrm{CI})$ $=6.155(2,437-15,554)$.

\section{B. Saran}

\section{Bagi Puskesmas Payung Sekaki Kecamatan Payung Sekaki}

Diharapkan kepada pihak Puskesmas lebih meningkatkan pelayanan dibidang promosi kesehatan dengan cara memberikan penyuluhan secara kontinyu dengan memperbanyak brosur atau leaflettentang penerapan 3M Plus diruang tunggu pasien sebagai salah satu upaya untuk meningkatkan pengetahuan dan sikap masyarakat baik dalam memberikan dukungan kepada keluarga yang menderita DBD maupun untuk penderita DBD sendiri dalam rangka menurunkan jumlah DBD khususnya di Kota Pekanbaru.

\section{Bagi Peneliti Selanjutnya}

Bagi peneliti selanjutnya yang ingin mengembangkan penelitian ini dengan desain yang berbeda dan diharapkan lebih menggali variabel lain yang berhubungan dengan Determina kejadian DBD dengan variabel penelitian yang berbeda seperti Peran petugas, dukungan kesehatan, media informasi, tokoh masyarakat sehingga peneliti lain dapat mengetahui apakah variabel tersebut mempengaruhi terhadap penerapan 3M Plus oleh penderita DBD yang ada di masyarakat

\section{DAFTAR PUSTAKA}


Adri. M. A., Jamil. F. K., Suhanda.R. (2016).

Hubungan Pengetahuan dan Sikap

Terhadap Tindakan Pencegahan Demam

Berdarah Dengue pada Masyarakat di

Kecamatan Baiturrahman. Jurnal Ilmiah mahasiswa medisia. 1(4), 1-5.

Anggraeni,Dini Siti. (2010). Stop Demam Berdarah Dengue. Bogor : Cita Insan Madani

Departemen Kesehatan Republik Indonesia 2005

Dewi, Ratna, S. (2015). Faktor Yang Mempengaruhi Perilaku Masyarakat Dalam Pemberantasan Sarang Nyamuk Demam Berdarah Dengue di Desa Rantau Rasau II Kecamatan Rantau Rasau. Scienta Journal. STIKes Prima Jambi. 4(1).

Indrawan, Mochamad. 2007. Biologi Konservasi. Jakarta :Yayasan Obor Indonesia

Misnadiarly. (2009). Demam Berdarah Dengue, Ekstrak daun jambu bisa untuk mengatasi DBD. Jakarta : Pustaka Populer Obor

Notoatmodjo, Soekidjo. (2007).

Metodologi Penelitian Kesehatan.

Jakarta: Rineka Cipta
Notoadmodjo, Soekidjo (2012). Promosi

Kesehatan dan Ilmu Perilaku. Jakarta: Rineka Cipta

Profile Departemen Kesehatan Nasional, (2015)

Profile Dinas Kesehatan Kota Pekanbaru, (2016)

Profile Puskesmas Payung Sekaki Kota

Pekanbaru, (2016)

Profile Kesehatan Provinsi Riau, (2015)

Satari, Hindra. (2004). Demam Berdarah.

Jakarta: Puspa Swara

Wahyono. M.Y.T. Haryono. B. Mulyono. S. Adiwibowo. A. (2010). Buletin Jendela Epidemiologi Demam Berdarah Dengue. Jakarta: Pusat Data dan Surveilans Epidemiologi Kementerian Kesehatan RI

Warsito, 2005. Hubungan perilaku masyarakat tentang penyakit DBD dengan Keberadaan jentik nyamuk aedes aegypti di kelurahan Sekejati Kota Bandung.

Puspaningrum Anggraeni Nindya (2004) Hubungan pengetahuan Masyarakat tentang penyakit DBD dengan perilaku $3 \mathrm{M}$ Plus Di Desa Sumbermulyo Kabupaten Bantul 